\title{
Dye-sensitized Solar Cell with the Electrode of Chlorophyll Derivative Adsorbed on Titanium Dioxide Film
}

\author{
Tasuku KOMORI and Yutaka AMAO* \\ Department of Applied Chemistry, Oita University (Dannoharu 700, Oita 870-1192, Japan) \\ Received June 25, 2002 ; Accepted November 21, 2002

\begin{abstract}
A dye-sensitized solar cell using a chlorine- $\mathrm{e}_{6}\left(\mathrm{Chl}_{\mathrm{e}}\right)$ derived from chlorophyll- $\alpha$, as visible and near-infrared sensitizer for nanocrystalline $\mathrm{TiO}_{2}$ films was developed. The short-circuit photocurrent density $\left(I_{\mathrm{sc}}\right)$, the open-circuit photovoltage $\left(V_{O C}\right)$, and the fill factor $(\mathrm{FF})$ of solar cell using $\mathrm{Chl}_{-} \mathrm{e}_{6}$ adsorbed on nanocrystalline $\mathrm{TiO}_{2}$ film electrode were estimated to be $0.305 \pm 0.012 \mathrm{~mA} \mathrm{~cm}{ }^{-2}, 426 \pm 10 \mathrm{mV}$, and $45.0 \%$, respectively. The overall photoenergy conversion efficiency $(\eta)$ was $0.73 \%$.
\end{abstract}

Key Words : Dye-sensitized Solar Cell, Chlorine-e, $\mathrm{e}_{6}$ Visible and Near-infrared Sensitization

\section{Introduction}

Dye-sensitized nanocrystalline solar cells have attracted much attention as low cost conventional prevailing photovoltaic cells. ${ }^{1)}$ In recent years, many studies on the dye-sensitized nanocrystalline solar cells have been reported. ${ }^{2-18)}$ The most successful photoinduced electron transfer sensitizers employed so far in these cells are ruthenium(II) polypyridyl complexes yielding overall photovoltaic conversion efficiencies was $10 \%$ in the dyesensitized nanocrystalline solar cells using ruthenium(II) polypyridyl complexes under light intensity of $100 \mathrm{~mW}$ $\mathrm{cm}^{-2}$, the equivalent of one sun at AM 1.5. ${ }^{2-4,16)}$ To improve further the performance of the dye-sensitized nanocrystalline solar cells using ruthenium(II) polypyridyl complexes, it is imperative to enhance their nearinfrared response. Metallo-phthalocyanines possess intense absorption band in the far-red and near-infrared region and excellent photostability, chemical and thermal stability. The dye-sensitized nanocrystalline solar cells using the far-red and near-infrared sensitization of methallophthalocyanines have been reported. ${ }^{17,18)}$ Despite their potential of the near-infrared sensitization, a methallophthalocyanines and ruthenium(II) polypyridyl complexes contain a heavy metal ion, these compounds would be undesirable photosensitizer from environmental

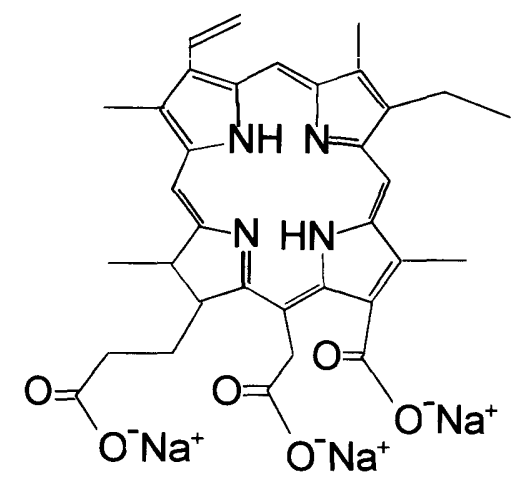

Fig. 1 Chemical structure of chlorine-e $($ Chl-e 6$)$. point of view. On the other hand, chlorophyll- $\alpha$, which act as an effective visible and near-infrared photosensitizer in photosynthesis of green plant, ${ }^{19)}$ has absorption maximum at $670 \mathrm{~nm}$. Thus, chlorophyll- $\alpha$ is an attractive compound for dye-sensitized solar cell as a photosensitizer in visible and near-infrared region. The carboxylic acid substitutents in $\mathrm{Ru}(\mathrm{II})$ polypyridyl complexes are essential for anchoring the dye on the surface of $\mathrm{TiO}_{2}{ }^{20.21}$ The carboxylate groups establish an electronic coupling with the $3 \mathrm{~d}$ conduction band orbital manifold of Ti. Chlorine- $\mathrm{e}_{6} \quad\left(\mathrm{Chl}_{-} \mathrm{e}_{6}\right)$, formed by the hydrolysis of chlorophyll- $\alpha$, was used in this work (the structure is shown in Fig. 1). As Chl-e $\mathrm{e}_{6}$ dose not contain a heavy metal ion, Chl- $\mathrm{e}_{6}$ can be an environment-friendly photosensitizer. As shown in Fig. 2, the absorption spectrum of Chl- $\mathrm{e}_{6}$ is similar to that of chlorophyll- $\alpha$, indicating the Chl- $\mathrm{e}_{6}$ is a attractive visible and near-infrared photosensitizer for dye-sensitized solar cell.

In this work Chl-e $\mathrm{e}_{6}$ derived from chlorophyll- $\alpha$ adsorbed nanocrystalline $\mathrm{TiO}_{2}$ film electrode was prepared

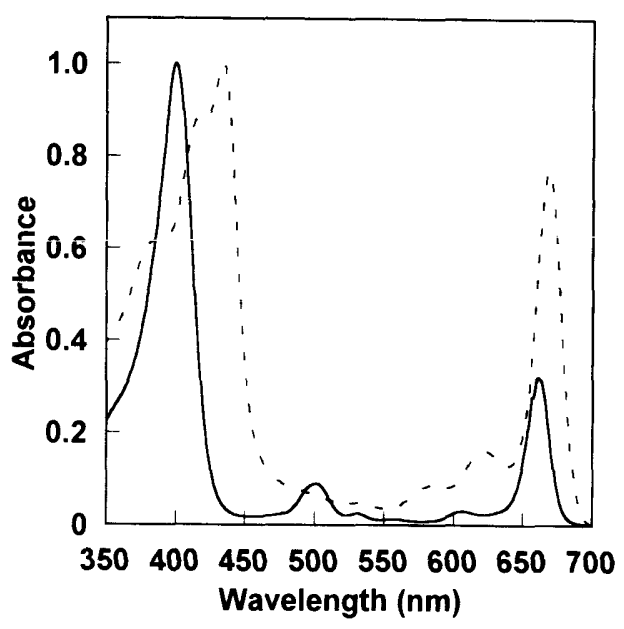

Fig. 2 UV-vis absorption spectra of Chl-e 6 (solid line) and chlorophyll- $\alpha$ (broken line) in methanol solution. 
and the photoelectrical properties of the solar cell using visible and near-infrared sensitization of nanocrystalline $\mathrm{TiO}_{2}$ film by $\mathrm{Chl}_{-} \mathrm{e}_{6}$ were investigated.

\section{Experimental}

Chl- $e_{6}$ trisodium salt and eosin-Y were purchased from Wako Chemical Co. Ltd. $\mathrm{TiO}_{2}$ powder (P25) was purchased from Degussa. The $0.05 \mathrm{~mol} \mathrm{dm}^{-3} \mathrm{I}_{2} / 0.5 \mathrm{~mol}$ $\mathrm{dm}^{-3} \mathrm{KI}$ in ethylene glycol / acetonitrile solution was obtained from Sol Ideas Technology Development. The other chemicals were analytical grade or the highest grade available. Conductive glass plate (10-15 $\Omega$ /square $\mathrm{SnO}_{2}$ : fluorine coated) was obtained from Nihon Sheet Glass Co. Ltd. The nanocrystalline $\mathrm{TiO}_{2}$ film was prepared by a similar procedure to that described in the literatures. ${ }^{2,5-9} \mathrm{TiO}_{2}$ powder was dispersed by grinding in concentrated nitric acid aqueous solution $(\mathrm{pH}=1.0)$. The viscous suspension was spread onto transparent conductive glass plate (OTE) $(5 \mathrm{~cm} \times 5 \mathrm{~cm})$ at room temperature using scotch tape as a spacer. A thin film was obtained by raking off the excess of suspension with a glass rod. After the tape was removed and the plate was dried using hot plate at $80^{\circ} \mathrm{C}$ for $30 \mathrm{~min}$, this plate was annealed at $450^{\circ} \mathrm{C}$ for 30 min under ambient condition to form a nanocrystalline $\mathrm{TiO}_{2}$ film electrode. The thickness of the film, determined by using a micron-sensitive caliper, was about $10 \mu \mathrm{m}$. A Chl-e $\mathrm{e}_{i}$ adsorbed nanocrystalline $\mathrm{TiO}_{2}$ electrode was prepared as follows. An OTE glass plate with a nanocrystalline $\mathrm{TiO}_{2}$ film was dipped into 0.2 mmol dm ${ }^{-3}$ methanol solution of $\mathrm{Chl}_{-} \mathrm{e}_{6}$ at room temperature for $24 \mathrm{~h}$. After dipping, the plate was washed with methanol several times and then the plate was dried under vacuum overnight. Photocurrent- photovoltage characteristic of Chl- $\mathrm{e}_{6}$ adsorbed nanocrystalline $\mathrm{TiO}_{2}$ electrode was measured with sandwich type cell. The working electrode with the Chl- $\mathrm{e}_{6}$ adsorbed on nanocrystalline $\mathrm{TiO}_{2}$ film was gently squeezed together with a carboncoated OTE glass electrode using spring and irradiated from the working electrode side. The $0.05 \mathrm{~mol} \mathrm{dm}^{-3} \mathrm{I}_{2} /$ $0.5 \mathrm{~mol} \mathrm{dm}^{-3} \mathrm{KI}$ in ethylene glycol / acetonitrile solution was used as the redox electrolyte. The solar cell using eosin-Y adsorbed on nanocrystalline $\mathrm{TiO}_{2}$ film electrode also was prepared as a standard solar cell. A $200 \mathrm{~W}$ tundsten lamp was used as light source for the photocurrent and photovoltage characteristics with the two digital multimeter with model 2000-J (Keithley) and model 34401 A (Agilent). The distance between the lamp and a test cell was $4.0 \mathrm{~cm}$. The active electrode area was typically 4.0 $\mathrm{cm}^{2}$. The light intensity on the surface of a test cell was $80 \mathrm{~mW} \mathrm{\textrm {cm } ^ { - 2 }}$ measured with laser power meter model AN/2 (Ophir Optronics, Inc). The fill factor (FF) is defined by

$$
\mathrm{FF}=I_{\mathrm{Ph}(\max )} V_{\mathrm{Ph}(\max )} / I_{\mathrm{SC}} V_{\mathrm{OC}}
$$

where $I_{\mathrm{Ph}(\max )}$ and $V_{\mathrm{Ph} \text { (max) }}$ are the photocurrent density and photovoltage for maximum power output and $I_{\mathrm{sc}}$ and $V_{\mathrm{OC}}$ are the short-circuit photocurrent density and opencircuit photovoltage. The overall photoenergy conversion efficiency $(\eta)$ is defined by the following equation:

$$
\eta=I_{\mathrm{sc}} V_{\mathrm{oc}} \mathrm{FF} / P_{\text {in }}
$$

Here $P_{\text {in }}$ is the power of incident white light.

A $200 \mathrm{~W}$ tungsuten lamp with optical color filter was used as a light source for the investigation of the effect of the wavelength of light source on the short-circuit photocurrent density of solar cell using $\mathrm{Chl}_{-} \mathrm{e}_{6}$ adsorbed on nanocrystalline $\mathrm{TiO}_{2}$ film electrode. The optical color filters used were blue filter (BLF-410B, wavelength of maximum transmittance: $370 \sim 480 \mathrm{~nm}$ ), green filter (GRF-533G, wavelength of maximum transmittance: 530 $\sim 550 \mathrm{~nm}$ ) and IR transmittance filter (SCF-60R, wavelength of maximum transmittance: $>600 \mathrm{~nm}$ ). The optical color filters were obtained from Sigma Koki Co. Ltd.

\section{Results and Discussion}

Figure 3 shows the photocurrent-photovoltage and power-photovoltage characteristics of a sandwich solar cell based on the Chl- $\mathrm{e}_{6}$ (solid line) and eosin-Y (dotted line) adsorbed on nanocrystalline $\mathrm{TiO}_{2}$ film electrode irradiated using $200 \mathrm{~W}$ tungsten lamp with a light intensity of $80 \mathrm{~mW} \mathrm{~cm}^{-2}$ as a light source. The $I_{\mathrm{sc}}$ and $V_{\mathrm{oc}}$, values of solar cell using Chl-e $\mathrm{e}_{6}$ adsorbed on nanocrystalline $\mathrm{TiO}_{2}$ film electrode were $0.305 \pm 0.012 \mathrm{~mA} \mathrm{~cm}{ }^{-2}$ and 426 $\pm 10 \mathrm{mV}$, respectively. The maximum power output and

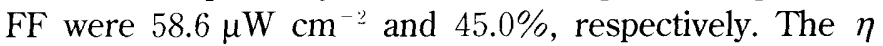
value calculated using eqn. (2) was estimated to be $0.73 \%$. For a eosin-Y adsorbed on nanocrystalline $\mathrm{TiO}_{2}$ film electrode, on the other hand, $I_{\iota}, V_{\varkappa}, \mathrm{FF}$ and $\eta$ were $0.205 \pm 0.020 \mathrm{~mA} \mathrm{~cm}-2,250 \pm 11 \mathrm{mV}, 38.0 \%$, and $0.02 \%$, respectively. The maximum power output was

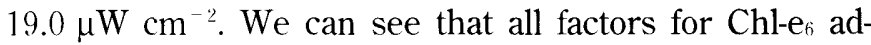
sorbed on nanocrystalline $\mathrm{TiO}_{2}$ film electrode are higher than those of the eosin-Y adsorbed electrode.

Next let us focus on the effect of wavelength region of light source on the short-circuit photocurrent density changes of the solar cell using Chl- $\mathrm{e}_{6}$ and eosin-Y adsorbed on nanocrystalline $\mathrm{TiO}_{2}$ film electrode. For solar cell using Chl- $\mathrm{e}_{6}$ adsorbed on nanocrystalline $\mathrm{TiO}_{2}$ film electrode, the photocurrents with the irradiation through

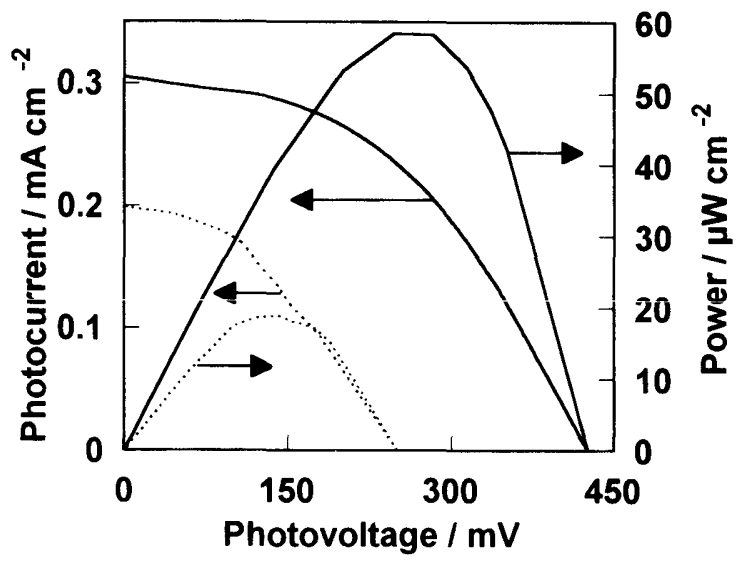

Fig. 3 Photocurrent-photovoltage and power-photovoltage characterizations of solar cell using Chl-e 6 (solid line) and eosin- $\mathrm{Y}$ (dotted line) adsorbed on nanocrystalline $\mathrm{TiO}_{2}$ film electrode with $200 \mathrm{~W}$ tungsten lamp as a light source. The light intensity was $80 \mathrm{~mW} \mathrm{~cm} \mathrm{~cm}^{-2}$. 
the blue, green, and IR transmittance filters were $0.101 \pm$ $0.011,0.090 \pm 0.008$, and $0.260 \pm 0.011 \mathrm{~mA} \mathrm{~cm}{ }^{-2}$, respectively. Especially, little change in the photocurrents between the irradiation with near-infrared region light and the irradiation without optical color filter $(0.305 \pm 0.012$ $\mathrm{mA} \mathrm{cm}{ }^{-2}$ ) was observed. The photoresponse of the Chl$\mathrm{e}_{6}$ adsorbed electrode extends well into the near-infrared region. Thus, the solar cell using visible and nearinfrared sensitization of Chl- $\mathrm{e}_{6}$ was achieved. For the solar cell using the eosin- $Y$ adsorbed on nanocrystalline $\mathrm{TiO}_{2}$ electrode, on the other hand, the photocurrents with the irradiation through the blue, green, IR transmittance filters and without optical filter were $0.04 \pm 0.011$, $0.16 \pm 0.016, \quad 0.007 \pm 0.0003$ and $0.205 \pm 0.020 \mathrm{~mA} \mathrm{~cm}{ }^{-2}$, respectively. The photocurrent decreased with the irradiation without optical color filters. Since the absorption band of eosin-Y is around at $520 \mathrm{~nm}$, little change in the photocurrents between the irradiation with green region light and the irradiation without optical color filter was observed. These results show that the visible and nearinfrared sensitized solar cell was attained using Chl- $\mathrm{e}_{6}$ adsorbed on nanocrystalline $\mathrm{TiO}_{2}$ electrode.

The photocurrent action spectrum and photocurrentphotovoltage characteristics of solar cell using Chl- $\mathrm{e}_{6}$ adsorbed on nanocrystalline $\mathrm{TiO}_{2}$ electrode under light intensity of $100 \mathrm{~mW} \mathrm{~cm} \mathrm{c}^{-2}$, the equivalent of one sun at AM 1.5 , are being studied in detail.

\section{Acknowledgement}

This work was partially supported by Special Fund from Venture Business Laboratory of Oita University and The Murata Science Foundation.

\section{References}

1) B. O' Regann and M. Grätzel, Nature, 353, 737 (1991).

2) M. K. Nazeeruddin A. Kay, I. Rodicio, R. HumphryBaker, E. Muller, N. Vlachpoulos, and M. Grätzel, J. Am. Chem. Soc., 115, 6382 (1993).

3) P. Pechy, F. P. Rotzinger, M. K. Nazeeruddin, O. Kohle, S. M. Zakeeruddin, R. Humphry-Baker, and M. Grätzel, J. Chem. Soc. Chem. Commun., 1995, 65.
4) N. Papageorigiou, Y. Athanassov, P. Bonhote, H. Pettersson, A. Azam, and M. Grätzel, J. Electrochem. Soc., 143, 3099 (1996).

5) Y. Wada, K. Tomita, K. Murakoshi, and S. Yanagida, $J$. Chem. Res. (S) , 1996, 320.

6) K. Murakoshi, R. Kogure, Y. Wada, and S. Yanagida, Chem. Lett., 1997, 471.

7) S. Nakade, S. Kambe, T. Kitamura, Y. Wada, and S. Yanagida, J. Phys. Chem. B, 105, 9150 (2001).

8) D. Zhang, S. Ito, Y. Wada, T. Kitamura, and S. Yanagida, Chem. Lett., 2001, 1042.

9) T. Kitamura, M. Maitani, M. Matsuda, Y. Wada, and S. Yanagida, Chem. Lett., 2001, 1054.

10) G. Smestad, C. Bignozzi, and R. Argazzi, Sol. Energy Mater. Sol. Cells, 32, 259 (1994).

11) C. Bechinger, S. Ferrere, A. Zaban, J. Sprague, and B. Gregg, Nature, 383, 608 (1996).

12) S.Y. Huang, G. Schlichthörl, M. Grätzel, and A. J. Frank, J. Phys. Chem. B, 101, 2576 (1997).

13) F. Cao, G. Oskam, P. Searson, J. M. Stipkala, T. Heimer, F. Farzad, and G. J. Meyer, J. Phys. Chem., 99, 17071 (1995).

14) M. Matsumoto, H. Miyazaki, K. Matsuhiro, $Y$. Kumashiro, and Y. Takaoka, Solid State Ionics, 89, 263 (1996).

15) R. Argazzi, C. Bignozzi, T. Hcimer, F. Castellano, and G. Meyer, Inorg. Chem., 33, 5741 (1994).

16) M. K. Nazeeruddin, P. Pechy, T. Renouard, S. M. Zakeeruddin, R. Humphry-Baker, P. Comte, P. Liska, L. Cevey, E. Coast, V. Shklover, L. Spiccia, G. B. Deacon, C. A. Bignozzi, and M. Grätzel, J. Am. Chem. Soc., 123, 1613 (2001).

17) H. Jianjun, G. Benkö, F. Korodi, T. Polívka, R. Lomoth, B. A kermark, L. Sun, A. Hagfeldt, and V. Sundström, J. Am. Chem. Soc., 124, 4918 (2002).

18) H. Jianjun, A. Hagfeldt, S. E. Lindquist, H. Grennberg, F. Kordi, L. Sun, and B. Ả kermark, Langmuir, 17, 2743 (2001).

19) H. Scheer, Chlorophylls 1991 ; CRC Press, London.

20) A. Hagfeldt and M. Grätzel, Chem. Rev., 95, 49 (1995).

21) A. Hagfeldt and M. Grätzel, Acc. Chem. Res., 33, 269 (2000). 